\title{
O presentismo e a realidade brasileira em perspectiva*
}

The presentism and the brazilian reality in perspective

HARTOG, François. Regimes de historicidade: presentismo e experiências do tempo. Belo Horizonte: Autêntica, 2013, 272 p.

\section{Walderez Simões Costa Ramalho}

walderezramalho@gmail.com

Mestrando

Universidade Federal de Minas Gerais

Rua Panamá, 144/301 - Sion

30320-120 - Belo Horizonte - MG

Brasil

Palavras chave

François Hartog; Regime de historicidade; Brasil.

Keywords

François Hartog; Regime of historicity; Brazil.

Recebido em: 16/6/2013

Aprovado em: 14/7/2013

*Agradeço à FAPEMIG pelo auxílio com a bolsa de pós-graduação, e aos colegas da disciplina "Produção e circulação do conhecimento histórico", ministrado pela professora Regina Horta Duarte no Programa de Pós-Graduação em História da Universidade Federal de Minas Gerais. 
A capa da revista Veja de 01 de agosto de 2012 é bastante significativa para o debate do livro analisado nesta resenha. Ela veicula o semblante abatido de José Dirceu sobre um fundo escuro, e sob o título: "Réu: o petista José Dirceu e mais 37 acusados no caso do mensalão começam a ler seu destino decidido nesta semana no 'julgamento do século' no Supremo Tribunal Federal, em Brasília".

Para além das disputas partidárias que envolvem o chamado "escândalo do mensalão", é interessante notar como se coloca o aspecto temporal no discurso da capa. O julgamento começou um dia após a publicação da revista, e terminaria com a condenação dos réus quatro meses e meio depois. No entanto, esse evento já é afirmado como um "fato histórico" - o "julgamento do século" - que selaria o futuro dos personagens envolvidos - os seus "destinos". Embora o verbo "começar" esteja conjugado no presente, seu complemento aponta ao mesmo tempo para o passado e o futuro; de modo que o final da história é decretado antes mesmo do evento concluir-se e no próprio instante em que teve início.

Esse tipo de articulação temporal expressa não apenas um viés "midiático" de interpretação do mundo político, mas também toda a cultura histórica contemporânea. E para refletir sobre essa questão, chegou ao Brasil um dos livros mais importantes de François Hartog, Regimes de historicidade: presentismo e experiências do tempo, lançado em 2013, com um excelente trabalho de tradução, dentro da Coleção História e Historiografia, elaborada pela Autêntica Editora e coordenada pela professora Eliana de Freitas Dutra. Embora Hartog já seja bastante conhecido e citado pelos historiadores brasileiros - com destaque para Fernando Nicolazzi (2010), Mateus Henrique Pereira (2011) e José Carlos Reis (2011) -, a publicação desse livro em português irá ampliar seus leitores e contribuir significativamente para o debate público nacional.

O conceito de "regime de historicidade", eixo central do livro, se define como o modo de articulação das três categorias do tempo (passado, presente e futuro) em uma dada sociedade e contexto histórico. Não se apresenta direta ou explicitamente na linguagem das fontes; é antes uma construção teórica com uma função heurística de ajudar "a melhor apreender, não o tempo, todos os tempos ou a totalidade do tempo, mas principalmente momentos de crise do tempo, aqui e lá, quando vêm justamente perder sua evidência as articulações do passado, do presente e do futuro" (HARTOG 2013, p. 37).

O conceito possui uma natureza essencialmente comparativa, pois se coloca na relação entre modos distintos de articular o tempo. Portanto, ele permite uma prática do "olhar distanciado", isto é, criar um distanciamento em relação ao presente "para, ao término da operação, melhor ver o próximo" (HARTOG 2013, p. 11).

O livro se situa no diálogo entre a antropologia de cunho estrutural e as reflexões de filósofos e historiadores sobre o tempo histórico. A primeira tem o seu lugar no livro, sobretudo com as obras de Claude Lévi-Strauss (1978) e Marshall Sahlins (1990), que enfatizam a diversidade de modos das sociedades 
se relacionarem com o tempo - como sintetiza o título de um dos capítulos do livro de Sahlins, "outras épocas, outros costumes", e que Hartog acrescenta: "mas outras histórias também" (HARTOG 2013, p. 50). Por outro lado, a noção de regime de historicidade também dialoga, por exemplo, com a proposta de Krzysztof Pomian (1984) em fazer uma história do próprio tempo, numa perspectiva filosófica; os estudos clássicos sobre o tempo histórico de Reinhart Koselleck (2006), especialmente os conceitos de "espaço de experiência" e "horizonte de expectativa" e as transformações envolvendo a estrutura da temporalidade com o advento da modernidade; e as reflexões de Paul Ricoeur (2010) sobre a configuração narrativa da experiência temporal; entre outros.

O autor elabora um percurso intelectual que lhe é característico: pensar a contemporaneidade a partir das idas e vindas entre os "antigos" e os "modernos". O autor revisita desde as sociedades aborígenes das ilhas do Pacífico, passando pelos gregos, os renascentistas e os herdeiros da revolução francesa, até chegar às "crises do tempo" do século XX que culminaram na queda do muro de Berlim. É nesse percurso historiográfico que a noção se estabelece, e não como uma obra teórica sobre um conceito explicativo. Nessas sociedades tão apartadas de nós no tempo, como pensar os seus regimes de historicidade? E em quais aspectos os homens do presente se diferenciam?

Para responder a essas questões, o autor divide o livro em duas partes. A primeira, intitulada "Ordem do tempo 1", aborda os antigos tipos-ideais de regimes de historicidade, visando "desnaturalizar" a nossa compreensão da ordem do tempo por meio do já citado "olhar distanciado". Hartog inicia o percurso pelo regime heroico, característico das sociedades antigas, no qual as construções míticas do passado - restrito às batalhas e ações dos reis são tomadas como esquemas de ação que conferem sentido aos eventos do presente, sob o signo da "repetição" e não do acontecimento único (paradigma da história moderna). A ascensão do regime cristão de historicidade operou significativas modificações, como a cisão do tempo em dois a partir do evento central da Encarnação: o nascimento, a morte e a ressureição do Filho de Deus feito homem. A novidade aqui é a tensão instaurada "entre o acontecimento decisivo pelo qual tudo já está concluído e o desfecho final que mostra bem que nem tudo ainda está acabado" (HARTOG 2013, p. 90).

A partir do século XVIII, houve novamente uma grande ruptura com a antiga ordem do tempo. O advento das luzes e as revoluções científicas, econômicas e sociais transformaram a experiência temporal: o foco passou a ser o "horizonte de expectativa", cada vez mais deslocado do "espaço de experiência". Surgiu então o regime moderno de historicidade, no qual o olhar é dirigido principalmente para o futuro, não mais como repetição do passado ou passível de previsões no presente; é o futuro do "progresso", do "aperfeiçoamento", que será necessariamente melhor que o ontem e o hoje. Nesse sentido, o regime moderno opera uma aceleração do tempo a partir da dominação do ponto de vista do futuro. O antigo topos da "história mestra da vida" (historia magistra 
vitæ) esfacelou-se, pois a experiência não serve mais como exemplo, já que o acontecimento passa a ser "único", "irrepetível". Vive-se para o futuro, e a história é escrita sob esse mesmo ponto de vista.

Essas considerações sobre a temporalidade moderna já foram discutidas por muitos historiadores, como o já citado Koselleck (2006). Marshall Berman (2007), em seu estudo clássico, também já havia discutido as mudanças engendradas pela experiência moderna do tempo a partir da produção literária e filosófica, destacando também a questão da aceleração do tempo histórico. Mas a grande novidade da obra de Hartog, sua mais importante interferência no debate contemporâneo sobre a temporalidade, reside na tese já citada segundo a qual as sociedades ocidentais presenciaram, no decorrer do século $X X$, uma progressiva cisão com o regime moderno de historicidade, pois a dimensão do presente passou a sobrepujar-se em relação ao passado e também ao futuro, caracterizando o regime presentista de historicidade. A noção é trabalhada na segunda parte do livro (Ordem do tempo 2).

A formação da ordem presentista do tempo ocorreu ao longo do século $X X$, o qual "se, em primeiro lugar ele foi mais futurista do que presentista, terminou mais presentista do que futurista" (HARTOG 2013, p. 140). O que exatamente provocou essa mudança? O ideal do progresso e a certeza de um futuro melhor foram abertamente questionados, de diversas maneiras e conjunturas, amplamente debatidas pelas Ciências Humanas e Literatura em geral: o mal-estar gerado pelas guerras mundiais; as contestações de 1968; o avanço da sociedade de consumo; o solapamento das identidades nacionais; o fortalecimento da globalização enquanto o processo de "compressão do espaço-tempo"; tudo isso levou a uma ênfase no presente e sua progressiva dilatação desproporcional em relação às outras categorias do tempo - processo que possui como marco simbólico de consolidação a queda do muro de Berlim, em 1989. Nesse processo, o presente fechou-se sobre si mesmo, tornou-se o seu próprio horizonte, num afastamento cada vez maior entre espaço de experiência e horizonte de expectativa. "Sem futuro e sem passado, ele produz diariamente o passado e o futuro de que sempre precisa, um dia após o outro, e valoriza o imediato" (HARTOG 2013, p. 148).

Esse presente dilatado mostra-se fragmentado e inconstante; e na sua volatilidade, também sente a necessidade de afirmar para si mesmo a sua raiz e a sua identidade, numa contradição de difícil solução. "Ele queria ser seu próprio ponto de vista sobre si mesmo e descobre a impossibilidade de se fiar nisso" (HARTOG 2013, p. 156). A crescente demanda das sociedades ocidentais por "memória" e "patrimônio", bem como a ampliação cada vez maior de seu campo de abrangência, indica a construção de um universo simbólico que sirva de referência para o presente e que busca a totalização. Essa estrutura de experiência temporal é altamente problemática, pois não consegue assimilar a "perda" como algo inerente do processo histórico: o presentismo identifica a perda como um apagamento de si, algo que só faz sentido a partir da sua busca 
em se tornar o ponto de vista absoluto do tempo. Muitos estudiosos seguiram essas considerações de Hartog, como o antropólogo Joël Candau (2011), que faz uma crítica a essa abordagem totalizante da memória e do patrimônio na formação das identidades nas sociedades ocidentais ditas "pós-modernas".

Como já foi dito, alguns historiadores brasileiros repercutiram esses conceitos de Hartog para refletir sobre a vida e o pensamento nacional. Um exemplo é Mateus Pereira (2011), que discute as possíveis relações entre a experiência presentista do tempo e o advento da chamada história do tempo presente, usando como fio condutor a ideia de que o presentismo tem como característica a tendência a uma historicização imediata. No entanto, em relação à produção historiográfica brasileira, o autor constata que esse tipo de abordagem ainda não se configurou como uma narrativa sobre eventos de visibilidade comum aos autores e leitores. No Brasil, a história do tempo presente é em grande medida a história da ditadura militar; quase nada se produziu, no âmbito da historiografia, sobre o período da chamada "redemocratização". Sem negar que o período militar ainda se reflete nas questões do presente, o autor registra que essa história é também do passado. Essa constatação leva Pereira a fazer uma crítica - entre outras - ao conceito de presentismo; este não seria uma evidência, mas permaneceria apenas como uma hipótese de trabalho. Entretanto, pode-se fazer uma objeção a essa crítica de Pereira, diferenciando "regime de historicidade" e "regime historiográfico": a experiência presentista do tempo não se expressa apenas nas obras de História, mas sim em diversos outros suportes de linguagem, como a imprensa, e até mesmo nas ações políticas, como procurarei demonstrar a seguir.

O regime presentista, em sua busca de tornar-se absoluto, mobiliza uma série de consequências políticas profundamente ambíguas, que podem ser depreendidas pela leitura do livro. Por um lado, leva à constatação de que não há alternativas para a ordem política majoritariamente instituída no presente, sobretudo nas sociedades ocidentais. A "democracia liberal" é muitas vezes representada pelas elites políticas e a mídia como um valor em si mesmo, inquestionável, desde já - e para todo o sempre - declarado "vencedor". O capitalismo globalizado apresenta-se como "natural", inelutável, a despeito de se pautar constantemente na "inovação" do próprio mercado. Por outro lado, se não há nenhum horizonte de "revolução", tampouco há experiências a serem "conservadas". Os costumes e os valores tradicionais são continuamente modificados de maneira a se "adequarem ao século XXI": é o caso das transformações no âmbito das relações de gênero, de sexualidade, na alimentação, educação, família, etc.

Em outras palavras, se no campo macropolítico o presentismo é "conservador", uma vez que não há perspectivas de mudanças do modelo liberal-democrático, no âmbito das microrrelações sociais ele é marcadamente "revolucionário", dado a volatilidade que lhe é intrínseco. Disto resulta uma série de complexidades e confusões, como a perspectiva de que ações de escopo 
imediato são suficientes para engendrar mudanças de amplitude histórica maior. É o caso, por exemplo, da recente implantação da política de cotas raciais para as universidades - reconhecidas pelos seus próprios defensores como medida paliativa, de "curto prazo" - sem o devido acompanhamento de mudanças estruturais no sistema público de educação - valorização da carreira do professor, melhorias de infraestrutura escolar, garantia de segurança no espaço da escola, e outras que só se realizam no "longo prazo". Essa forma de lidar com o tempo na política não se traduz apenas como demagogia ou iniciativa de reparação histórica: é, sobretudo, um sintoma da ausência de perspectiva temporal para além do agora, do instante. A implantação das cotas por si só configura-se como uma solução imediatista para problemas estruturais e de alcance histórico/ temporal mais profundo.

Essa ambiguidade é um dos reflexos dessa "crise do tempo" característica do regime presentista. Frequentemente vivenciamos acontecimentos declarados precipitadamente como "históricos", embora não apresentem qualquer consequência de maior profundidade. O julgamento do mensalão é um exemplo - entre muitos outros de escândalos políticos tematizados pela imprensa em geral. "A economia midiática do presente não cessa de produzir e de utilizar o acontecimento, [...] com uma peculiaridade: o presente, no momento mesmo em que se faz, deseja olhar-se como já histórico, como já passado" (HARTOG 2013, p.149-150).

É exatamente isto o que se percebe na capa citada acima. Em que pese o discurso de Veja, não houve efetivamente nenhuma grande transformação na vida política brasileira causada em função da condenação dos réus. Apesar de figuras importantes envolvidas no escândalo terem sido presos, muitos continuam exercendo influência significativa nas decisões do governo, o qual não sofreu grandes abalos no grau de aceitação e legitimidade perante a população, como esperava grande parte dos seus opositores. Quer se denomine "sensacionalismo" ou estratégia de marketing da revista, é evidente o apelo ao instante como algo já "histórico", isto é, dotado de uma profundidade temporal desproporcional: o discurso já o representa como algo já passado ("o julgamento do século") e determinante para todo o porvir ("destino definido") a partir da sua realização no presente ("começam... nesta semana"). A pretensão da revista em declarar em 2012 o acontecimento do século e determinante para todo o futuro no momento mesmo em que teve início demonstra com toda a clareza essa forma presentista - e problemática - de articular e dar significado à experiência temporal.

A proclamação da história já realizada antes mesmo do evento se concluir demonstra a ampliação desmesurada do presente, em detrimento do passado e do futuro. Essa forma de articular o tempo não é exclusiva da chamada "grande mídia" no Brasil, mas um elemento da cultura histórica consolidada em 1989. Com efeito, o discurso da capa de Veja possuía de fato algum "sentido" no momento de sua publicação; esse sentido é a própria evidência do regime presentista de historicidade, e o discurso a expressão do presentismo. Desse 
modo, a iniciativa de se publicar Regimes de historicidade é bastante louvável, pois a obra traz muitos elementos para se pensar a realidade brasileira no (e sobre o) presente.

\section{Referências bibliográficas}

BERMAN, Marshall. Tudo que é sólido desmancha no ar: a aventura da modernidade. São Paulo: Companhia das Letras, 2007.

CANDAU, Joël. Memória e Identidade. São Paulo: Editora Contexto, 2011.

KOSELLECK, Reinhart. Futuro Passado: contribuição à semântica dos tempos históricos. Rio de Janeiro: Editora PUC-RJ; Contraponto, 2006.

LÉVI-STRAUSS, Claude. Raça e história. In:

Os pensadores. São Paulo: Abril Cultural, 1978.

NICOLAZZI, Fernando. A história entre tempos: François Hartog e a conjuntura historiográfica contemporânea. História: Questões \& Debates. Curitiba, n. 53, p. 229-257, jul/dez 2010.

PEREIRA, Mateus H. F. A história do tempo presente: do futurismo ao presentismo? Humanidades. Brasília, v.58, p.56-65, 2011.

POMIAN, Krzysztof. L'Ordre du temps. Paris: Gallimard, 1984.

REIS, José Carlos. O tempo histórico como "representação cultural". Sophie. Recife, n.1, p.8-29, abril de 2011.

RICOEUR, Paul. Tempo e narrativa. Tradução de Claudia Berliner. São Paulo: Martins Fontes, 2010. 3vol.

SAHLINS, Marshall. Ilhas de história. Rio de Janeiro: Jorge Zahar, 1990. 